\title{
Synchronization of flowering in maize (Zea mays L.) by the genetic system pg11 pg12
}

\author{
LL. Bosch ${ }^{1}$, F. Casañas ${ }^{1}$ and F. Nuez ${ }^{2}$ \\ ${ }^{1}$ Departamento de Biologia, Escola Superior d'Agricultura, Urgell, 187, Barcelona 08036, Spain; \\ ${ }^{2}$ Departamento de Genética, Escuela de Ingenieros Agrónomos de Valencia, Camino de Vera 14, \\ Valencia 46022, Spain
}

Received 28 October 1987; accepted in revised form 2 February 1988

Key words: Zea mais, maize, pg11 pg12, near-isolines, hybrid seed, flowering synchronization

\section{Summary}

The mutant genotype pg11pg11 pg12pg12 - epistasis of double recessive factors - determines greater precocity of flowering. The possibility of using this mutant in the production of hybrid seed as a mean of synchronizing flowering in parent strains of different earliness is studied. The differences between mutant and green control genotypes in the characters of days to pollen shedding, pollen production, and height of plants are evaluated. Four mutant lines are considered together with their respective green near-isolines in two distinct localities and across four successive plantings.

The mutant near-isolines presented lower values than those of the green near-isolines for all the characters. The maximum reductions in days to flowering were obtained in early plantings and late maturity strains. The reduction in pollen production was about $50 \%$. The reduced height of the mutants is explained, at least in part, by the correlation of this factor with days to flowering. The mutants did not prove to be more sensitive to the environment than their green near-isolines. Seed production was not studied since the mutant is very deficient for this character and it could therefore only be utilized as the male parent. We concluded that the mutant, could be used to synchronize flowering in the industrial production of hybrid seed.

\section{Introduction}

The simultaneous flowering of parent plants is essential to the production of hybrid maize seed. Therefore, it is necessary to control this process precisely in order to cross materials of different earliness. Proposed methods of accomplishing this include clipping young plants (Cloninger et al., 1974), coating seeds with germination retarding products (Bauman, 1967), and delayed planting of the earlier parent. Delayed planting is the most commonly used method in practice (Craig, 1977). Petroleum mulch (Anonymous, 1980) and plastic films (David, 1981) have also been successfully used to advance flowering.

Although, in principle, a genetic solution to the problem would be more satisfactory, those used so far have had little success. These methods have been based on the use of Mendelian mutants to retard flowering. This is the case with the gene for indeterminate growth (id) which retards flowering in a haphazard way. The presence of the duplicate genes pale green-11 (pg11) and pale green-12 (pg12) in double homozygous condition produces the opposite effect inducing precocity (Bosch, et al., 1979). However this advance in flowering is 
Table 2. \% of variation and statistical significance of each effect. The significance has been obtained through the $\mathrm{F}$ statistic of the corresponding ANOVA

\begin{tabular}{|c|c|c|c|c|c|c|c|c|c|}
\hline Source of variation & $\mathrm{L}_{1} \mathrm{P}_{1}$ & $\mathrm{~L}_{1} \mathrm{P}_{2}$ & $\mathrm{~L}_{1} \mathrm{P}_{3}$ & $\mathrm{~L}_{1} \mathrm{P}_{4}$ & $\mathrm{~L}_{2} \mathrm{P}_{1}$ & $\mathrm{~L}_{2} \mathrm{P}_{2}$ & $\mathrm{~L}_{2} \mathrm{P}_{3}$ & $\mathrm{~L}_{2} \mathrm{P}_{4}$ & Trait \\
\hline Genetic background (Fg) & $9^{* *}$ & $27^{* *}$ & $26^{* *}$ & $31^{* *}$ & $19^{* *}$ & $17^{* *}$ & $14^{* *}$ & $25^{* *}$ & \multirow{4}{*}{$\begin{array}{l}\text { Days to } \\
\text { pollen } \\
\text { shedding }\end{array}$} \\
\hline Colour $(\mathrm{C})$ & $60^{* *}$ & $38^{* *}$ & $46^{* *}$ & $33^{* *}$ & $41^{* *}$ & $42^{* *}$ & $22^{* *}$ & $15^{* *}$ & \\
\hline $\mathrm{Fg} \times \mathrm{C}$ & $17^{* *}$ & $10^{* *}$ & $8^{* *}$ & $11^{* *}$ & $5^{* *}$ & $9^{* *}$ & 6 & 0 & \\
\hline Residual (R) & 14 & 25 & 20 & 25 & 35 & 32 & 58 & 60 & \\
\hline $\mathrm{Fg}$ & $19^{* *}$ & $14^{* *}$ & $21^{* *}$ & $15^{* *}$ & $42^{* *}$ & $29^{* *}$ & $23^{* *}$ & $23^{* *}$ & \multirow{4}{*}{$\begin{array}{l}\text { No. of } \\
\text { tassel } \\
\text { branches }\end{array}$} \\
\hline $\mathrm{C}$ & $54^{* *}$ & $67^{* *}$ & $45^{* *}$ & $62^{* *}$ & $39^{* *}$ & $33^{* *}$ & $26^{* *}$ & $47^{* *}$ & \\
\hline $\mathrm{Fg} \times \mathrm{C}$ & 1 & 2 & $3^{*}$ & $3^{*}$ & 0 & $14^{* *}$ & $25^{* *}$ & 3 & \\
\hline $\mathrm{R}$ & 26 & 17 & 31 & 20 & 19 & 24 & 26 & 27 & \\
\hline $\mathrm{Fg}$ & $4^{* *}$ & $48^{* *}$ & $51^{* *}$ & 2 & $57^{* *}$ & $60^{* *}$ & $52^{* *}$ & $47^{* *}$ & \multirow{4}{*}{$\begin{array}{l}\text { Plant } \\
\text { height }\end{array}$} \\
\hline C & $52^{* *}$ & $35^{* *}$ & $18^{* *}$ & $44^{* *}$ & $27^{* *}$ & $22 * *$ & $17^{* *}$ & $23^{* *}$ & \\
\hline $\mathrm{Fg} \times \mathrm{C}$ & 3 & $3^{*}$ & $4^{*}$ & $9^{* *}$ & $6^{* *}$ & $2^{*}$ & 0 & $12^{* *}$ & \\
\hline $\mathrm{R}$ & 41 & 14 & 27 & 45 & 10 & 16 & 31 & 18 & \\
\hline
\end{tabular}

${ }^{*} \mathrm{p}<0.05$.

${ }^{* *} \mathrm{p}<0.01$.

these plantings. The significant interaction $\mathrm{FgC}$ (Table 2) is attributed to the observation that the difference between mutant and control tends to increase as the cycle becomes longer (Fig. 1). This behaviour can also be explained just as well by the scaling effect mentioned above. These results are favorable for the practical use of the character, because greater reductions are obtained: 1 ) in early plantings, and 2) in late flowering genotypes, both conditions where the highest interest lies in reducing flowering date. An advance in flowering of 19 days was obtained in the genetic stock BA $1 \times$ first planting at the locality of Torrebonica.

Number of tassel branches. Although late planting reduced the number of tassel branches (Table 3), the size of the effect was of little importance.

Table 3. No. of tassel ramifications of green $(G)$ and pale green (PG) near-isolines for each combination $\mathrm{L}_{\mathrm{i}} \mathrm{P}_{\mathrm{j}}$

\begin{tabular}{llllll}
\hline Planting & \multicolumn{2}{l}{ Torrebonica $\left(\mathrm{L}_{1}\right)$} & & \multicolumn{2}{l}{ Girona $\left(\mathrm{L}_{2}\right)$} \\
\cline { 2 - 3 } \cline { 5 - 6 } \cline { 5 - 6 } & $\mathrm{G}$ & $\mathrm{PG}$ & & $\mathrm{G}$ & $\mathrm{PG}$ \\
$\mathrm{P}_{1}$ & 15.88 & 7.73 & & 16.87 & 8.97 \\
$\mathrm{P}_{2}$ & 17.69 & 5.92 & & 15.98 & 8.86 \\
$\mathrm{P}_{3}$ & 15.17 & 8.3 & & 13.37 & 7.86 \\
$\mathrm{P}_{4}$ & 13.54 & 5.29 & & 14.17 & 6.34 \\
\hline
\end{tabular}

The system pg11pg12 reduces the number of tassel branches by $50 \%$ on average (Table 3 ). Color is the most important effect, followed by genetic background, the interaction $\mathrm{Fg} \times \mathrm{C}$ being much less important (Table 2). When the pale green lines are compared with their green near-isolines within the same genetic background, one observes reductions in the number of branches between 6.2 and 9.4 (Table 4).

The reduction in pollen production (estimated by the number of tassel branches) is an important disadvantage, as the pale green strain is to be used as the male parent. However, other proposed methods of synchronizing flowering based on damaging the plants in the first stages of growth also have this disadvantage. For example clipping young plants, Cloninger et al. (1974) caused reduc-

Table 4. No. of tassel branches according to genetic background, in green $(\mathrm{G})$, and mutant (PG) near-isolines

\begin{tabular}{lcc}
\hline Genetic background & $\mathrm{G}$ & $\mathrm{PG}$ \\
\hline BA 1 & & \\
BA 2 & 17.3 & 11.1 \\
BA 3 & 13.4 & 4 \\
BA 4 & 19.3 & 10.8 \\
& 11.3 & 3.7 \\
\hline
\end{tabular}


tions of $50 \%$ in pollen production and a differential of flowering of 6.5 days. In contrast, application of petroleum mulch or plastic film on the soil increased pollen production between 0 and $200 \%$ and precocity of flowering by 3-7 days according to experiments in France (David, 1981). In climates where temperature is less of a limiting factor the difference in flowering time is reduced considerably, as we have proved in experiments carried out in Barcelona (results unpublished). On the other hand, in comparison with the genetic method being studied, this treatment is much more difficult to apply. The low production of pollen in the pale green plants could be corrected by increasing their proportion in hybrid seed fields.

Height of the plant. Mutant plants attained a significantly lower height than the controls in all $\mathrm{L}_{\mathrm{i}} \mathrm{P}_{\mathrm{j}}$ combinations (Tables 2 and 5). This could present difficulties for the dissemination of pollen. The effect of the genetic background was highly significant while the interaction of genetic background and colour was of little importance (Table 2). The reduction in plant height associated with the pale green system varies between 13 and $33 \mathrm{~cm}$ among the distinct genetic backgrounds (Table 6). The shorter height of the mutants was a result of their having fewer internodes of the same average length.

Genetic background was at least as important as colour (Table 2). In Table 1, one can observe that the pale green near-isolines BA2-PG and BA3-PG showed similar heights to those of lines $\mathrm{MC}$ and W64A of similar cycles. Similar results were obtained in the near-isoline BA1-PG with respect to

Table 5. Height $(\mathrm{cm})$ of green near-isolines $(\mathrm{G})$ and mutant near-isolines $(\mathrm{PG})$ for each combination $\mathrm{L}_{\mathrm{i}} \mathrm{P}_{\mathrm{i}}$

\begin{tabular}{lrrllr}
\hline Planting & \multicolumn{2}{l}{ Torrebonica $\left(\mathrm{L}_{1}\right)$} & & \multicolumn{2}{l}{ Girona $\left(\mathrm{L}_{2}\right)$} \\
\cline { 2 - 3 } \cline { 5 - 6 } \cline { 5 - 6 } & $\mathrm{G}$ & $\mathrm{PG}$ & & $\mathrm{G}$ & PG \\
\hline $\mathrm{P}_{1}$ & 106 & 81 & & 135 & 99 \\
$\mathrm{P}_{2}$ & 108 & 75 & & 134 & 108 \\
$\mathrm{P}_{3}$ & 102 & 82 & & 122 & 98 \\
$\mathrm{P}_{4}$ & 87 & 64 & & 120 & 90 \\
\hline
\end{tabular}

BA2-G. The low height in near-isoline BA4-PG can be attributed to the genetic material as the respective green near-isoline is also extremely short.

Sensitivity to environment. Mutants, their green near-isolines and the remaining four green control lines were analyzed separately using triple factorial ANOVAS for location (L), planting date (P), and genotype (Table 7). The residual effect was less important for the group of four green control lines across all the characters, the green near-isolines showing the greatest values. Therefore, this greater sensitivity to uncontrolled environmental factors must be attributed to the genetic background rather than to the mutant genotype. The mutant near-isolines did not show significantly higher values $(\mathrm{p}<0.05)$ to the four green control lines for the controlled environmental variables, location and planting date (Table 7). Only the effect of planting date $\times$ genotype, on height showed results significantly higher for the mutants than for the four green control lines.

As a conclusion, the experiment indicates that the pale green system incorporated into late flowering genetic stocks and in early plantings, advances flowering time between 3 and 19 days, reduces the number of tassel branches by $50 \%$, and diminishes height to a degree similar to that of control materials of the same cycle and different genetic background. The sensitivity of the pale green strains to the environment is no greater than that of the respective green near-isolines.

Table 6. Height (cm) according to genetic background, in green (G) and mutant (PG) near-isolines

\begin{tabular}{lcr}
\hline Genetic background & G & PG \\
\hline BA 1 & 132 & 102 \\
BA 2 & 105.1 & 72.2 \\
BA 3 & 134.9 & 122.2 \\
BA 4 & 86.6 & 53.7 \\
\hline
\end{tabular}


Table 7. Components of variance of the effects which indicate sensitivity to the environment and to the interaction genotype $\times$ environment, in the mutant near-isolines (PG), the green near-isolines (G) and the remaining green lines (V)

\begin{tabular}{|c|c|c|c|c|c|c|c|c|c|c|}
\hline \multirow[t]{2}{*}{ Sensitivity to } & \multirow{2}{*}{$\begin{array}{l}\text { Source of } \\
\text { variation }\end{array}$} & \multicolumn{3}{|c|}{ Days to flowering } & \multicolumn{3}{|c|}{ No. of tassel branches } & \multicolumn{3}{|c|}{ Plant height } \\
\hline & & PG & G & $\mathrm{V}$ & PG & G & V & PG & G & V \\
\hline \multirow[t]{4}{*}{ Environment } & $\mathrm{L}$ & $10^{* *}$ & $1 \cdot 4^{* *}$ & $2 \cdot 9^{* *}$ & $0 \cdot 5^{* *}$ & $0 \cdot 1$ & $0 \cdot 3^{* *}$ & $259^{* *}$ & $346^{* *}$ & $177^{* *}$ \\
\hline & $\mathrm{P}$ & $8 \cdot 4^{* *}$ & $17 \cdot 4^{* *}$ & $7^{* *}$ & $0 \cdot 8^{* *}$ & $1 \cdot 9^{* *}$ & $0 \cdot 5^{* *}$ & $33^{* *}$ & $67^{* *}$ & $47 \cdot 4^{* *}$ \\
\hline & $\mathrm{L} \times \mathrm{P}$ & $7 \cdot 7^{* *}$ & $8 \cdot 3^{* *}$ & $8 \cdot 9^{* *}$ & $0 \cdot 6^{* *}$ & $0 \cdot 6^{* *}$ & $0 \cdot 2^{*}$ & $17^{* *}$ & $7 \cdot 2^{* *}$ & $21 \cdot 5^{* *}$ \\
\hline & Residual & 14 & $16 \cdot 3$ & $11 \cdot 5$ & $11 \cdot 7$ & 20 & $4 \cdot 6$ & 265 & 294 & 196 \\
\hline Interaction & $\mathrm{L} \times \mathrm{G}_{\mathrm{e}}$ & $2 \cdot 2^{* *}$ & $3^{* *}$ & $2 \cdot 9^{* *}$ & $6 \cdot 4^{* *}$ & $1 \cdot 2^{* *}$ & $2 \cdot 2^{* *}$ & $102^{* *}$ & $90^{* *}$ & $36^{* *}$ \\
\hline genotype $\left(\mathrm{G}_{\mathrm{e}}\right) \times$ & $\mathrm{P} \times \mathrm{G}_{\mathrm{e}}$ & $1 \cdot 4^{* *}$ & $0 \cdot 5^{*}$ & $1 \cdot 3^{* *}$ & $0 \cdot 5^{* *}$ & $1 \cdot 8^{* *}$ & $0 \cdot 5^{* *}$ & $15^{* *}$ & $1 \cdot 2$ & $10^{* *}$ \\
\hline environment & $\mathrm{L} \times \mathrm{P} \times \mathrm{G}_{\mathrm{e}}$ & $0 \cdot 5$ & 0 & $4^{* *}$ & $0 \cdot 7$ & $0 \cdot 4$ & $0 \cdot 5^{* *}$ & $26 \cdot 5^{* *}$ & $18^{*}$ & $45 \cdot 3^{* *}$ \\
\hline
\end{tabular}

${ }^{*} \mathrm{p}<0.05$.

${ }^{* *} \mathrm{p}<0.01$.

\section{Acknowledgements}

This work has been done with a grant from La Caixa de Pensions de Catalunya i Balears.

\section{References}

Anonymous, 1980. Essay mulch. A.G.P.M. Pau. France.

Bauman, L.F., 1967. Seed coating to delay emergence. 22nd Hybrid Corn Industry-research Conf.

Bosch, LL., M. Blanco, A. Alvarez \& J.L. Blanco, 1979. Relationship between pg11 pg12, earliness and modification of some parts of the plants. Maize Genetics Cooperation News Letter 53: 8-9.
Bosch, LL., F. Casañas \& F. Nuez, 1987. Comparison among different genotypes pale green-11 pale green-12. Proceedings of 14th Eucarpia Maize and Sorghum section Congress. pp. 98-105.

Cloninger, F.D., M.S. Zuber \& R.D. Horrocks, 1974. Synchronization of flowering in corn (Zea mays L.) by clipping young plants. Agronomy J. 66: 270-272.

Craig, W.F., 1977. Production of Hybrid Corn Seed. In: G.F. Sprague (Ed.). Corn and Corn Improvement, 671-719. Agronomy 18. Amer. Society of Agron. Madison.

David, S., 1981. Production de semences de maïs: que peut-on attendre du paillage plastique? A.G.P.M. Pau. France.

Gavazzi, G., C. Piccardo \& L. Manzoni, 1975. A study of the effects of temperature and nutrients on the expression of chlorophyll mutants in maize. Zeitschrift für Pflanzenphysiologie 75: 381-391. 